\title{
Public Value of Working Women towards the Practice of Exclusive Breastfeeding and the Provision of Nursing Room
}

\author{
Frieda NR Hidayati ${ }^{1}$, Hardi Warsono ${ }^{2}$, Retno Sunu Astuti ${ }^{3}$, Hartuti Purnaweni ${ }^{4}$, J. Warella ${ }^{5}$ \\ \{psifriedanrh@gmail.com ${ }^{1}$ \} \\ Universitas Diponegoro, Indonesia ${ }^{1,2,3,4,5}$
}

\begin{abstract}
Mothers who have to return to work after giving birth and having 3-month maternity leave are facing challenges in giving exclusive breastfeeding, which should be given for the first 6 months, and decided to use formula milk. The Regulation of the Minister of Health of the Republic of Indonesia Number 15 of 2013 concerning Procedures for Providing Special Facilities for Breastfeeding and/or Expressing Breastmilk has been ineffective. This preliminary study was a desk research reviewing the practice of exclusive breastfeeding in working women and their needs of nursing rooms in their workplace. The method used in the study was literature review on the research in the recent 10 years regarding women's attitudes and knowledge towards exclusive breastfeeding and the needs of nursing rooms. The results of this study indicate that there is still a socio-cultural influence on the values, attitudes and knowledge of women regarding the obligation to provide breast milk to their babies, work obligations and the availability of nursing rooms in their workplace. This research has practical benefits regarding the effectiveness of exclusive breastfeeding and the provision of nursing rooms in Indonesia.
\end{abstract}

Keywords: Public Value, Working Woman, Exclusive Breastfeeding

\section{Introduction}

The percentage of working women increases annually. Based on a research, in 2006, the percentage was recorded as 48,6\% and increased to $51,25 \%$ in 2008 and most of working women are in childbearing age [1]. When a working woman has become pregnant and gave birth to her child, there is an obligation for her to take care of and especially is to give breast milk to her baby. In accordance with the rules of employment, women who work and give birth will obtain the right to have their maternal leave for three months. Mothers, who return to their workplace after 3 months of maternity leave, have difficulty in giving exclusive breast milk and decide to use formula milk. Exclusive breastfeeding is the provision of breastmilk without any additional food for babies aged 0-6 months. Breastmilk is the best food that should be given to babies because it contains almost all the nutrients the baby needs. The government's concern over the importance of breastfeeding and the breastfeeding practice is indicated by the establishment of Government Regulation 33/2012 on Granting Exclusive Breastfeeding.

Exclusive breastfeeding in Indonesia is alarming and needs a lot of attention from all parties. Awareness of mothers to exclusively breastfeed is very low and shows a decline from year to year. In 2008, the practice of exclusive breastfeeding was only 24,3\%, increased in 2009 to $34,3 \%$, and declined to $15,3 \%$ in 2010 while the target to be achieved was $80 \%$. The low level 
of exclusive breastfeeding has become the trigger for low nutritional status in infants and toddlers and can be an indirect cause of mortality in infants. Exclusive breastfeeding has not carried out due to internal factors, including insufficient milk production, problems with sucking, lack of motivation and knowledge of mothers, and external factors, namely family support, healthcare workers and condition of working mothers which does not allow her to provide exclusive breastfeeding. The government established a policy as a guideline for the practice of exclusive breastfeeding in in the Regulation of the Minister of Health of the Republic of Indonesia Number 15 of 2013 concerning Procedures for Providing Special Facilities for Breastfeeding and/or Expressing Breastmilk.

To ensure the practice of exclusive breastfeeding, comprehensive information is needed about the benefits of breastfeeding. In addition, support from management and the work environment is needed. Several policies have been established to support the practice of breastfeeding among working mothers. In Joint Regulations of 3 Ministers (Minister of Empowerment of Women and Child Protection, Minister of Manpower and Transmigration and Minister of Health) No.48/MEN.PP/XII/2008, PER.27/MEN/XII/2008 and 1177/MENKES/PB/XII/2008 on Allowing Mothers to Express Breast Milk during Working Hours in the Workplace, working mothers are entitled to protection and support for breastfeeding in the workplace and to exclusively breastfeed their babies as well as express their breastmilk in the workplace. It is expected that working mothers are protected and supported for practicing breastfeeding in the workplace. Providing opportunities is the length of time given to working women to breastfeed their babies, according to the availability of nursing room in accordance with the conditions and capabilities of the institution. In Chapter V, article 30 in Government Regulation 33/2012 on Granting Exclusive Breastfeeding establishes the implementation of exclusive breastfeeding in the workplace. Workplace must provide special facilities for breastfeeding and/or expressing breast milk, in accordance with the conditions and capacity of the enterprise. Workplace and Public Facilities must support exclusive breastfeeding in accordance with company regulations that govern relations between employers and workers or through agreements between union workers and employers. Research conducted in Malang [2] and Padang [3] shows that both policies are ineffective. Other problems that generally occur are the duration of breastfeeding practice and the availability of nursing room. Another problem that also arises is the question of whether maternity leave for working mothers can be given during exclusive breastfeeding (six months) instead of three months as implemented so far.

\subsection{Problem Formulation}

As established in Joint Regulations of 3 Ministers (Minister of Empowerment of Women and Child Protection, Minister of Manpower and Transmigration and Minister of Health), working mothers are entitled to protection and support for breastfeeding in the workplace and to exclusively breastfeed their babies. Article 83 of Act No. 13 of 2003 concerning Manpower establishes that female workers/ labourers whose babies still need breastfeeding are entitled to breastfeed their babies if that must be performed during working hours. Chapter V, article 30 in Government Regulation 33/2012 on Granting Exclusive Breastfeeding establishes the implementation of exclusive breastfeeding in the workplace. Working mothers are entitled to breastfeed by taking into account the place and facilities in accordance with the conditions and capabilities of the company. The policy is stated in the Regulation of the Minister of Health of the Republic of Indonesia Number 15 of 2013 concerning Procedures for Providing Special Facilities for Breastfeeding and/or Expressing Breastmilk. 
Problems arise when the policies that have been established are less effective in their implementation, based on the following indicators:

1. High percentage of working mothers who do not exclusively breastfeed.

2. Many working mothers feel constrained to provide exclusive breastfeeding for their babies.

3. Nursing rooms are not available in every workplace, both in private or government institution.

4. The controversy over whether a woman should breastfeed her baby in public space, especially there is no nursing room.

Act No. 13 of 2003 concerning Manpower, article 83 in Joint Regulations of 3 Ministers

(Minister of Empowerment of Women and Child Protection, Minister of Manpower and Transmigration and Minister of Health) (No.48/MEN.PP/XII/2008, PER.27/MEN/XII/2008 and 1177/MENKES/PB/XII/2008) on Allowing Mothers to Express Breast Milk during Working Hours in the Workplace, article 30 in Government Regulation 33/2012 on Granting Exclusive Breastfeeding, Regulation of the Minister of Health of the Republic of Indonesia Number 15 of 2013 concerning Procedures for Providing Special Facilities for Breastfeeding and/or Expressing Breastmilk should be established, otherwise:

1. Health-related problems in children would likely to occur, threatening the achievement of nation's objective: the golden generation in 2045.

2. If the policies are neglected, there are possibilities that more women will not be able to carry out their obligations to provide breast milk or, in other words, they have lost their rights as mothers.

3. Policies should be established to support the achievement of nation's objective: the golden generation in 2045.

\subsection{Research Question}

How does the public value of women contribute to exclusive breastfeeding policy and the provision of nursing room facilities?

Specifically, the aims of the study were:

1. Examining various previous studies related to the policy and implementation of exclusive breastfeeding.

2. Examining the supporting and inhibiting factors in working mothers to practice exclusive breastfeeding for six months and create the public value of working mothers towards exclusive breastfeeding and the provision of nursing rooms.

\section{Research Methodology}

The research is a preliminary study to examine the contributing factors to the public value of working mothers towards the policy regarding exclusive breastfeeding and the provision of nursing room facilities that have been established by the government of the Republic of Indonesia which are considered less effective.

Literature review is used in this research to see the extent of research that has been carried out in Indonesia and in other countries. The stages of the literature review are as follows:

1. Determine the period of publication to be reviewed, namely the last 10 years (2011-2020).

2. Determining the form of publication. This research review journals and proceedings. 
3. Time and form of publication and the publisher, which were also included as the inclusion criteria in this literature review.

The journals used in the study were obtained through the database of international journal provider SpringerLink and Indonesian scientific journals were obtained through google scholar.

The search for journals in SpringerLink and google scholar is based on the following keyword: public value, working mothers, exclusive breastfeeding, which resulting in 2,867 articles. Those articles were sorted based on the year and conformity to the research question. The filtering process was based on PICOT (Problem/population, Implementation/intervention. Control, Outcome, and Time) resulting in 62 articles as the source for literature review.

\section{Results and Discussion}

Reviews on 62 articles are categorized into: 1) The practice of exclusive breastfeeding; 2) Women as mothers and workers; 3 ) Social/community factor.

\subsection{The practice of exclusive breastfeeding}

A research conducted by Heymann, Raub, and Earle [4] shows that the government policy which guarantee breastfeeding breaks for working mothers is significantly related to the level of exclusive breastfeeding. In contrast, another research conducted by Iswarno, Hasanbasri and Lazuardi [5] shows less committed local government to Maternal and Neonatal Care program and lack of stakeholder involvement during the program planning and budgeting process. Bosi et al. [6] shows that the practice of breastfeeding in European countries, especially exclusive breastfeeding is far from WHO recommendation. Those researchers also compared breastfeeding practices, child feeding policies and the proportion of baby-friendly hospitals in various countries. Gupta et al. [7] concluded that there is a lack of attention to exclusive breastfeeding in Government policies in almost all countries. The finding is in line with another research conducted by Duysburgh et al. [8], which suggests that the implementation of policies related to newborns in most countries is weak because the implementation is only monitored in health sector, yet remains ambiguous as seen from substandard services for newborn care. Infrastructure is important in supporting mother's wishes regarding exclusive breastfeeding [9].

\subsection{Women as Mothers and Workers}

Women who got married, pregnant, and bear responsibility as mothers face many challenges yet, researches on the needs of women after labor are limited [10]. This study also discusses a main challenge observed in mothers, namely: the helplessness of caring for babies because of the increased role of being a mother in addition to being a worker, healthcare services which have not provided optimal support and in particular, healthcare services for a woman's transition to motherhood. Probandari et al. [11], explore the obstacles in the implementation of healthcare services for mothers and babies, which are rooted in the understanding of mothers and other family members about postnatal care. Regarding the availability of nursing room, $50.4 \%$ of women as the subject of a study conducted by Ward and Hackett [12], felt less supported. Women decided not to breastfeed, because of cultural and psychological factors that make them feel uncomfortable when they have to breastfeed their babies. Several factors such as mother's age, education, socioeconomic status determine their attitude. A study from 
Mufdlilah et al. [9], concluded that it is necessary to increase women's knowledge/understanding about exclusive breastfeeding. Factors from the female side are also seen in the study of Buss [13] which stated that in women, a positive attitude towards exclusive breastfeeding is needed, but more women who do not have enough knowledge about breastfeeding will experience anxiety regarding inadequate breastfeeding. Two studies conducted by Altamimi et al. [14] and Basrowi et al. [15], both suggest that working mothers decided not to continue the practice of exclusive breastfeeding due to work-related reasons.

\subsection{Social/Community Factor}

Research conducted by Basrowi et al. [15], shows that it is necessary to evaluate the policies regarding exclusive breastfeeding, especially in the context of the work environment, because the increasing number of working mothers is a threat to the continuation of exclusive breastfeeding for the child's first six months. The consideration was based on the regulation that mothers are only entitled for a 3-month maternity leave. There is an urge to create a breastfeeding-friendly environment in workplaces according to the study conducted by Altamimi et al. [14]. Buss [13] concluded the need to improve the situation of a more breastfeeding-friendly environment. In their study, Mufdlilah et al. [9], suggested that infrastructure is important in supporting women's will regarding exclusive breastfeeding. Cultural and community behavior contribute to mother's decision to provide and maintain the continuity of breastfeeding, as concluded by Betts and Russell [16] so that a strategy to create insightful community that supports women is important. Regarding the location of breastfeeding, there is still controversy about whether breastfeeding is a private act or something that can be done in public places, according to the research by Ward and Hackett [12]. The role of healthcare workers in exclusive breastfeeding is considered important as stated in a study conducted by Gurning et al. [17]. The statement supports the findings of a study by Probandari et al. [11], regarding the pattern of sociocultural responses of healthcare service in community.

\section{Conclusion}

1. Practice of exclusive breastfeeding among working mothers is still lower that the expected level.

2. The inhibiting factor is the public value in women, which is determined by internal and external factors such as surrounding community and its culture.

\section{References}

[1] Y. Prameswari and I. N. Sari, "Sibling Rivalry: Gambaran Dinamika Pengetahuan, Sikap dan Reaksi Ibu," Ensiklopedia J., vol. 1, no. 4, 2019.

[2] R. Rini, C. Sasmito, and C. I. Gunawan, "Implementasi kebijakan penyediaan ruang laktasi di Kota Malang," AcTion Aceh Nutr. J., vol. 3, no. 1, pp. 34-41, 2018.

[3] I. Gusmelia, N. I. Lipoeto, and H. Hardisman, "Implementasi Kebijakan Penyediaan Ruang Menyusui di Kota Padang," J. Kesehat. Andalas, vol. 8, no. 1, pp. 151-157, 2019.

[4] J. Heymann, A. Raub, and A. Earle, "WHO brochure»," Bull. World Health Organ., vol. 91, pp. 398-406, 2013.

[5] I. Iswarno, M. Hasanbasri, and L. Lazuardi, "Analisis Untuk Penerapan Kebijakan: Analisis Stakeholder dalam Kebijakan Program Kesehatan Ibu dan Anak di Kabupaten Kepahiang," J. 
Kebijak. Kesehat. Indones. JKKI, vol. 2, no. 2, pp. 77-85, 2013.

[6] A. T. B. Bosi, K. G. Eriksen, T. Sobko, T. M. A. Wijnhoven, and J. Breda, "Breastfeeding practices and policies in WHO European region member states," Public Health Nutr., vol. 19, no. 4, pp. 753-764, 2016.

[7] A. Gupta, S. Suri, J. P. Dadhich, M. Trejos, and B. Nalubanga, "The world breastfeeding trends initiative: implementation of the global strategy for infant and young child feeding in 84 countries," J. Public Health Policy, vol. 40, no. 1, pp. 35-65, 2019.

[8] E. Duysburgh et al., "Newborn care in Indonesia, Lao People's Democratic Republic and the Philippines: a comprehensive needs assessment," BMC Pediatr., vol. 14, no. 1, p. 46, 2014.

[9] M. Mufdlilah, M. Akhyar, E. Sutisna, and A. A. Subijanto, "Association of government policy and mother's perception to exclusive breastfeeding practice," Belitung Nurs. J., vol. 2, no. 6, pp. 115-122, 2016.

[10] E. Erfina, W. Widyawati, L. McKenna, S. Reisenhofer, and D. Ismail, "Exploring Indonesian adolescent women's healthcare needs as they transition to motherhood: A qualitative study," Women and Birth, vol. 32, no. 6, pp. e544-e551, 2019.

[11] A. Probandari, A. Arcita, K. Kothijah, and E. P. Pamungkasari, "Barriers to utilization of postnatal care at village level in Klaten district, central Java Province, Indonesia," BMC Health Serv. Res., vol. 17 , no. 1, p. $541,2017$.

[12] C. Mulready-Ward and M. Hackett, "Perception and attitudes: breastfeeding in public in New York City," J. Hum. Lact., vol. 30, no. 2, pp. 195-200, 2014.

[13] I. M. Buss, "Knowledge, Attitudes and Behaviours Towards Exclusive Breastfeeding Amongst Mothers in Sarawak, Malaysia: A Qualitative Study," IIUM Med. J. Malaysia, vol. 18, no. 1, 2019.

[14] E. Altamimi, R. Al Nsour, D. Al dalaen, and N. Almajali, "Knowledge, attitude, and practice of breastfeeding among working mothers in South Jordan," Workplace Health Saf., vol. 65, no. 5, pp. 210-218, 2017.

[15] R. W. Basrowi et al., "Challenges and supports of breastfeeding at workplace in Indonesia," Pediatr. Gastroenterol. Hepatol. Nutr., vol. 21, no. 4, pp. 248-256, 2018.

[16] J. Betts and R. Russell, "Breastfeeding: Attitude and Policies," Northern Ireland Assemblyresearch and information service, 2017. [Online]. Available: http://www.niassembly.gov.uk/assembly-business/committees/2016-2017/committee-forhealth/research-papers-2017/breastfeeding-attitudes-and-policies/.

[17] F. P. Gurning, M. Y. Pratama, and M. Ratodi, "The Exclusive Breastfeeding Policies Implementation and Health Workers Roles in Medan-Indonesia," 2018. 